\title{
Clostridium frigidicarnis sp. nov., a psychrotolerant bacterium associated with 'blown pack' spoilage of vacuum-packed meats
}

\author{
D. M. Broda, ${ }^{1,2}$ P. A. Lawson, ${ }^{3}$ R. G. Bell ${ }^{2}$ and D. R. Musgrave \\ Author for correspondence: D. M. Broda. Tel: +64 78548550 . Fax: +64 78548560 . \\ e-mail : d.broda@mirinz.org.nz
}
1,2 Department of Biological Sciences, University of Waikato', and MIRINZ Food Technology \& Research, PO Box 6172 . Hamilton, New Zealand
3 Department of Food Science and Technology, University of Reading, Reading RG6 6BZ, UK

\begin{abstract}
Two strains of a psychrotolerant Clostridium, isolated from vacuum-packed, temperature-abused beef, were characterized using a multiphasic approach. The strains were Gram-positive motile rods producing elliptical subterminal spores during early stationary growth phase. The strains were psychrotolerant. At pH 7.0, they grew between 3.8 and $40.5{ }^{\circ} \mathrm{C}$; their optimum growth temperature was $30.0-38.5{ }^{\circ} \mathrm{C}$. At $30^{\circ} \mathrm{C}$, the $\mathrm{pH}$ range for growth was between 4.7 and 9.5; the optimum pH for growth was 6.4-7.2. The organisms were proteolytic and saccharolytic, lecithinase-positive and hydrolysed gelatin. The fermentation products formed in peptone/yeast extract/glucose/starch broth were acetate, ethanol, butyrate, isovalerate, butanol, isobutyrate, oxalacetate, lactate, hydrogen and carbon dioxide. The DNA G+C compositions of the two meat strains were 27.3 and $28.4 \mathrm{~mol} \%$. Phylogenetic analyses indicated that the strains belong to Cluster I of the genus Clostridium (sensu Collins et al., 1994). The new strains differed from phylogenetically related clostridia in terms of cellular fatty acid composition, soluble protein profiles and phenotypic properties. On the basis of phenotypic and genotypic characterization data, the strains were assigned to a new species for which the name Clostridium frigidicarnis is proposed; strain SPL77A' (= DSM 12271') is the type strain.
\end{abstract}

Keywords: Clostridium frigidicarnis, psychrotolerance, meat spoilage

\section{INTRODUCTION}

Historically, Clostridium species were believed to play only a minor role in meat spoilage (Gill, 1979; Roberts \& Mead, 1986). Early reports (Ingram, 1952; Callow \& Ingram, 1955; Ross, 1965) regarded mesophilic clostridia and Clostridium putrefaciens, which is atypical with respect to its growth temperature range, as the causative agents of deep tissue spoilage ('bone taint') of beef and/or cured hams. Clostridium-mediated 'bone taint' spoilage was believed to have been eliminated by the development of chilled storage and modern packaging technologies (Roberts \& Mead, 1986). However, more recently, psychrotolerant (psychrophilic) Clostridium species have been recog-

Abbreviations: CFA, cellular fatty acids; FAME, fatty acid methyl esters; FC, final concentration; FID, flame ionization detector.

The GenBank accession number for the 16S rRNA gene sequence of strain SPL77A ${ }^{\top}$ is AF069742. nized as the causative agents of 'blown pack' spoilage of vacuum-packed meat (Dainty et al., 1989; Kalchayanand et al., 1989; Broda et al., 1996). Similarly, production of offensive, sickly odours in vacuum-packed cooked pork has been attributed to the growth of a psychrotolerant Clostridium species (Lawson et al., 1994). These types of meat spoilage occur during chilled storage in the absence of temperature abuse.

To date, three psychrotolerant meat spoilage-causing species of clostridia have been described: Clostridium estertheticum (Collins et al., 1992), Clostridium laramiense (Kalchayanand et al., 1993; Trüper \& De' Clari, 1997) and Clostridium algidicarnis (Lawson et al., 1994). However, the results obtained from a slaughter stock survey that included faecal, hide and tonsil samples (J. A. Boerema, D. M. Broda \& R. G. Bell, unpublished results), as well as examination of spoiled vacuum packs (Broda et al., 1996), indicate that numerous species of psychrotolerant clostridia, 
including some spoilage-causing strains, may be commonly associated with slaughter stock and vacuumpacked meat. It appears, therefore, that the detection of psychrotolerant Clostridium species as a group in vacuum-packed meat may no longer be sufficient to account for premature meat spoilage at refrigeration temperatures. Consequently, to effect spoilage control it is necessary first to determine which clostridial species are causing the spoilage and second to trace the causative micro-organism back to its reservoir of contamination in the meat plant.

The aim of this study was to describe and characterize a psychrotolerant Clostridium species associated with a meat spoilage incident. These data may also provide a means to differentiate this new species from other psychrotolerant clostridia, both spoilage-causing and benign, that may be encountered in spoiled vacuum packs and the meat plant environment. Such differentiation will facilitate tracing spoilage-causing clostridia to their reservoirs within the abattoir.

\section{METHODS}

General procedures. Unless stated otherwise, stringent anaerobic procedures (Holdeman et al., 1977) were used for culturing all Clostridium strains and for physiological and substrate utilization tests. All anaerobic media that contained reducing agents were pre-reduced by cooling after sterilization inside an anaerobic chamber (Forma Scientific) operating with an anaerobic gas mixture $\left(10 \%, \mathrm{v} / \mathrm{v} \mathrm{H}_{2} ; 5 \%\right.$, $\mathrm{v} / \mathrm{v} \mathrm{CO}_{2} ; 85 \%, \mathrm{v} / \mathrm{v} \mathrm{N}_{2}$ ). Only fully reduced media, as indicated by the colourless state of resazurin indicator in the medium, were used for tests.

Bacteria. Strains SPL77A ${ }^{\mathrm{T}}(\mathrm{T}=$ type strain) and SPL77B were initially isolated from the same 'blown' temperatureabused vacuum pack of raw beef using methods described previously (Broda et al., 1996). After their initial isolation, strains SPL77A ${ }^{\mathrm{T}}$ and SPL77B were maintained as freezedried cultures. Before characterization, both strains were revived from freeze-dried material in peptone/yeast extract/ glucose/starch (PYGS) broth (Lund et al., 1990), subcultured onto Columbia Blood Agar (CBA; Oxoid) containing $5 \%(\mathrm{v} / \mathrm{v})$ sheep blood (Life Technologies) and incubated at $30^{\circ} \mathrm{C}$ for $48 \mathrm{~h}$. Strains were checked for purity before use.

Reference strains of Clostridium cadaveris (DSM 1284 $)$, Clostridium fallax $\left(\mathrm{DSM} 2631^{\mathrm{T}}\right)$, Clostridium intestinale (DSM 6191 ${ }^{\mathrm{T}}$ ) and Clostridium carnis (DSM 1293 ${ }^{\mathrm{T}}$ ) were obtained from the Deutsche Sammlung von Mikroorganismen und Zellkulturen GmbH, Braunschweig, Germany. A reference strain of $C$. algidicarnis $\left(\mathrm{NCFB} 2931^{\mathrm{T}}\right.$ ) was obtained from the National Collection of Food Bacteria, Reading, UK. All reference strains were revived from freezedried material in PYGS broth and checked for purity by plating onto CBA supplemented with $5 \%(\mathrm{v} / \mathrm{v})$ sheep blood. With the exception of $C$. algidicarnis, which was grown at $30^{\circ} \mathrm{C}$, reference strains were grown at $37^{\circ} \mathrm{C}$.

\section{Phenotypic characterization}

(i) Morphology and ultrastructure. For description of colony morphology, strains SPL77 $\mathrm{A}^{\mathrm{T}}$ and SPL77B were grown on the surface of CBA with $5 \%(\mathrm{v} / \mathrm{v})$ sheep blood at $30^{\circ} \mathrm{C}$ for
$48 \mathrm{~h}$. The morphology of well-isolated colonies was described.

For descriptions of vegetative cell and spore morphology, meat strains were grown in PYGS broth at $30^{\circ} \mathrm{C}$ for $18 \mathrm{~h}$ and $5 \mathrm{~d}$, respectively. A light microscope (Leitz Orthoplan) in phase-contrast mode was used to examine and photograph vegetative cells and spores of each bacterium. Presence of flagella was determined in 18-h-old cultures of strains SPL 77A ${ }^{\mathrm{T}}$ and SPL77B. For this determination, the cultures were washed with water, allowed to settle onto Formvarcoated copper grids and negatively stained with 1-2\% (w/v) uranyl acetate (Beveridge et al., 1994). Stained grids were dried and examined with a transmission electron microscope (Philips EM 400).

The ultrastructure of vegetative cells and spores was determined for the isolates grown in PYGS broth at $30^{\circ} \mathrm{C}$ for $18 \mathrm{~h}$ and $5 \mathrm{~d}$, respectively. The bacteria were fixed overnight at $4{ }^{\circ} \mathrm{C}$ in a solution containing $2.5 \%(\mathrm{v} / \mathrm{v})$ glutaraldehyde in $100 \mathrm{mM}$ sodium cacodylate buffer $(\mathrm{pH} 7 \cdot 2)$. The fixed cells were washed in $100 \mathrm{mM}$ sodium cacodylate buffer and postfixed with $1 \%(\mathrm{w} / \mathrm{v})$ aqueous osmium tetroxide. The cells were then stained en bloc with $4 \%(\mathrm{w} / \mathrm{v})$ aqueous uranyl acetate, dehydrated and embedded in Spurr embedding medium. Ultra-thin sections were then prepared and stained with a $4 \%(\mathrm{w} / \mathrm{v})$ uranyl acetate and lead citrate solution (Beveridge et al., 1994). The grids containing sections were examined with a transmission electron microscope.

(ii) Gram reaction, Gram-type and cell wall type. Exponentially growing (at $30^{\circ} \mathrm{C}$ for $18 \mathrm{~h}$ ) cells of strains SPL77A $\mathrm{A}^{\mathrm{T}}$ and SPL77B were Gram stained using the method of Johnson et al. (1995). A KOH test (Powers, 1995) was additionally conducted to determine the Gram-type of cells grown on the surface of CBA with $5 \%(\mathrm{v} / \mathrm{v})$ sheep blood at $30^{\circ} \mathrm{C}$ for $18 \mathrm{~h}$. Cell wall type was determined using transmission electron microscopy, as described in the previous section.

(iii) Physiological tests. For physiological tests, growth was determined by monitoring an increase in $\mathrm{OD}_{550}$, as measured with a spectrophotometer (Novaspec II; Pharmacia), against three uninoculated controls.

The potential for growth at $25 \mathrm{pH}$ values ranging from $4 \cdot 23$ to 9.82 was determined at $30{ }^{\circ} \mathrm{C}$ in peptone/yeast extract (PY) broth (Holdeman et al., 1977) with glucose concentration adjusted to $0 \cdot 5 \%(\mathrm{w} / \mathrm{v})$. Broths were inoculated with $2 \%(\mathrm{v} / \mathrm{v})$ culture growing exponentially at $\mathrm{pH} 7 \cdot 0$. The $\mathrm{pH}$ of the broth was kept constant $( \pm 0 \cdot 1$ unit) by adjustment with potassium phosphate buffer. The broth $\mathrm{pH}$ was measured with a $\mathrm{pH}$ meter (Schott CG 837; Labsupply Pierce) equipped with a combination electrode. Cultures were incubated for up to $10 \mathrm{~d}$ to determine whether growth occurred.

Growth rates were measured for 43 temperatures ranging from -1.5 to $47.0^{\circ} \mathrm{C}$. The temperature range for growth was determined at $\mathrm{pH} 7.0$ in PY broth with $0.5 \%(\mathrm{w} / \mathrm{v})$ glucose. Hungate tubes containing medium were inoculated with $2 \%(\mathrm{v} / \mathrm{v})$ culture growing exponentially at $30^{\circ} \mathrm{C}$ and incubated in a temperature gradient incubator of local manufacture. Throughout the study, temperatures were monitored with copper constatan thermocouples and a Comark 1624 electronic thermometer. Tubes were incubated for up to $21 \mathrm{~d}$ to determine whether growth occurred.

(iv) Biochemical characteristics. All biochemical tests were conducted in duplicate. Unless otherwise stated, consensus 
duplicate results were required for the final results to be recorded as positive or negative.

Substrate utilization was tested according to Holdeman et al. (1977) at $30^{\circ} \mathrm{C}$ and initial $\mathrm{pH} 7.0$ in PY broth containing $0.1 \%(\mathrm{w} / \mathrm{v})$ yeast extract. The substrates were $(1 \%, \mathrm{w} / \mathrm{v}$ concentration, except where noted): adonitol $(0.5 \%, \mathrm{w} / \mathrm{v})$, arabinose $(0.5 \% \mathrm{w} / \mathrm{v})$, cellobiose, dextran, fructose, galactose, glucose, inositol, inulin, lactose, maltose, mannitol, rhamnose, raffinose, salicin, sorbitol, sorbose, sucrose, trehalose $(0.5 \%, \mathrm{w} / \mathrm{v})$ and xylose. Hungate tubes containing the medium with substrate and duplicate controls with no substrate were inoculated with $2 \%(\mathrm{v} / \mathrm{v})$ culture exponentially growing in PYGS broth at $30^{\circ} \mathrm{C}$. Changes in $\mathrm{OD}_{550}$ and $\mathrm{pH}$ were monitored. Tubes showing an increase in OD of more than $0 \cdot 1$ OD unit, as compared with controls, were recorded as positive with respect to substrate utilization. Tubes showing a $\mathrm{pH}$ drop of more than $1.0 \mathrm{pH}$ unit, as compared with controls, were recorded as positive with respect to substrate fermentation.

Gelatin hydrolysis, lecithinase and lipase activities, milk reaction, meat and casein digestion, indole production, nitrate reduction, oxidase and catalase production, urea hydrolysis, ammonia and hydrogen sulphide production, aesculin and starch hydrolysis, and growth in the presence of bile and Tween 80 were tested following methods of Holdeman et al. (1977). The Rapid ID 32 A system (bioMérieux) was used to study an additional 29 enzymic reactions: urea hydrolysis, arginine dihydrolase activity, fermentation of 11 sugars, glutamic acid decarboxylase activity, nitrate reduction, indole production, alkaline phosphatase activity and arylamidase activity towards 12 amino acids. Test strips were inoculated according to the manufacturer's instructions and read after aerobic incubation at $37^{\circ} \mathrm{C}$ for $4 \mathrm{~h}$.

Fermentation products were determined for strains SPL77A $^{\mathrm{T}}$ and SPL77B grown in PYGS broth at $30^{\circ} \mathrm{C}$ for $5 \mathrm{~d}$. Ether extracts of volatile fatty acids and alcohols, and methyl esters of non-volatile fatty acids were prepared according to Holdeman et al. (1977). Extracts were analysed on a Hewlett Packard 5890/II GC equipped with a $30 \mathrm{~m} \times 0.53 \mathrm{~mm}, 1.0 \mu \mathrm{m}$ FFAP capillary column (J\&W Scientific), a flame ionization detector (FID) and a Hewlett Packard model 7673 automatic sampler. The GC parameters were as follows: column head pressure, $47 \cdot 4 \mathrm{kPa}$; split vent flow of helium carrier gas, $50 \mathrm{ml} \mathrm{min}^{-1}$; column flow measured at $60^{\circ} \mathrm{C}, 9.9 \mathrm{ml} \mathrm{min}^{-1}$; resultant split ratio, $5: 1$; split/splitless injector and FID detector temperature, $260{ }^{\circ} \mathrm{C}$. Run conditions were: initial temperature $60^{\circ} \mathrm{C}$ for $2 \mathrm{~min}$, raised to $180^{\circ} \mathrm{C}$ at $5^{\circ} \mathrm{C} \mathrm{min}{ }^{-1}$, final temperature of $240^{\circ} \mathrm{C}$ held for $2 \mathrm{~min}$ after raising at a rate of $20^{\circ} \mathrm{C} \mathrm{min}^{-1}$. Peaks were automatically integrated (Chemstation v.4) and fatty acids were identified and quantified against retention times and peak areas of known standards. Results of duplicate experiments were recorded as a concentration range for a product. Production of $\mathrm{H}_{2}$ and $\mathrm{CO}_{2}$ was determined on a Varian GC equipped with a Porapak Q 80/100-mesh column (Supelco) and a thermal conductivity detector. This test was qualitative only.

(v) Toxicity test. To test for lethality of the culture supernatant of strain SPL77A ${ }^{\mathrm{T}}$, procedures described in the FDA Bacteriological Analytical Manual (Solomon et al., 1995) for detection of botulinal neurotoxin were followed. National Animal Ethics Committee approval was granted before testing began. Strain SPL77A ${ }^{\mathrm{T}}$ was grown for $5 \mathrm{~d}$ at $30^{\circ} \mathrm{C}$ in cysteine- and resazurin-deficient PYGS broth. An undiluted, trypsin- and heat-treated culture supernatant was prepared and injected intraperitoneally into mice. For each sample, a separate pair of mice was injected. Mice were observed periodically over $72 \mathrm{~h}$.

\section{Genotypic characterization}

(i) DNA isolation. Meat isolates were grown in PYGS broth at $30^{\circ} \mathrm{C}$ for $18 \mathrm{~h}$ and were harvested by centrifugation at $12000 \mathrm{~g}$ for $15 \mathrm{~min}$. Cells were washed twice with saline/ EDTA $(0 \cdot 15 \mathrm{M} \mathrm{NaCl}, 1 \mathrm{mM}$ EDTA, pH 8.0). DNA was isolated using the method of Marmur (1961) modified as described by Johnson (1994). Briefly, cells were lysed with lysozyme at a final concentration (FC) of $50 \mathrm{mg} \mathrm{ml}^{-1}$, followed by $\mathrm{SDS}(\mathrm{FC} 2.5 \%, \mathrm{w} / \mathrm{v})$ and proteinase $\mathrm{K}(\mathrm{FC}$ $50 \mu \mathrm{g} \mathrm{ml}^{-1}$ ) lysis. The lysate was repeatedly deproteinized with phenol, phenol/chloroform (1:1) and chloroform, DNA was precipitated with absolute ethanol and spooled onto a glass rod. DNA was washed, dried and dissolved in TE buffer (10 mM Tris, $1 \mathrm{mM}$ EDTA, pH 8.0). RNase A treatment (FC $50 \mu \mathrm{g} \mathrm{ml}^{-1}$ ) was used to remove RNA from the solution, followed by repeated deproteinization. The DNA solution was dialysed against ice-cold TE and stored at $-20^{\circ} \mathrm{C}$.

DNA concentration was measured by a fluorimetric dyebinding method (Hoechst 33258) using a fluorimeter (Hoeffer DynaQuant 200; Biolab Scientific). The procedure recommended by the fluorimeter's manufacturer was followed. Calf thymus DNA (Sigma) was used as a standard.

(ii) Determination of DNA base composition. $\mathrm{G}+\mathrm{C}$ composition was determined in DNA from strains SPL77A ${ }^{\mathrm{T}}$ and SPL77B, and in DNA from Escherichia coli $\mathrm{B}(51.0 \mathrm{~mol} \%$; Sigma) by the method of Mesbah et al. (1989). DNA was denatured

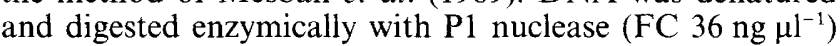

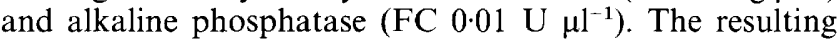
nucleosides were separated using a reverse-phase HPLC equipped with a $1.5 \mathrm{~m} \times 4.6 \mathrm{~mm}, 3 \mu \mathrm{m}$ Econosphere C18 column (Alltech Associates), and fractions were quantified. $\mathrm{G}+\mathrm{C}$ composition was calculated using the mole fractions of deoxyguanosine and thymidine against the $E$. coli standard.

(iii) $16 \mathrm{~S}$ rRNA sequence determination. The $16 \mathrm{~S}$ rRNA sequences of strains SPL77A ${ }^{\mathrm{T}}$ and SPL77B were determined by direct sequencing of the purified PCR-amplified 16S rDNA fragment.

Genomic DNA was used as the PCR template. PCR was performed with universal (eu)bacterial primers complementary to conserved regions of the $5^{\prime}$ and $3^{\prime}$ ends of the $16 \mathrm{~S}$ rRNA gene. The primer sequences were (Hutson et al., 1993): pA (forward) 5'-AGA GTT TGA TCC TGG CTC AG-3' (approx. positions $8-28$ in $E$. coli numbering) and $\mathrm{pH}^{*}$ (reverse) 5'-AAG GAG GTG ATC CAG CCG CA-3' (approx. positions 1542-1522 in E. coli numbering).

The PCR mix was prepared according to the manufacturer's (Boehringer Mannheim) recommendation and contained: PCR buffer $10 \times(10 \mu \mathrm{l}), 0.2 \mathrm{mM}$ each deoxynucleoside triphosphate, $0.5 \mu \mathrm{M}$ each primer, $2.5 \mathrm{U}$ Taq polymerase and $10 \mu \mathrm{l}$ template DNA $(100 \mathrm{ng})$ in a total volume of $100 \mu \mathrm{l}$. Amplifications were performed in a heated lid thermal cycler (Techne Genius; John Morris Scientific). After initial denaturation for $3 \mathrm{~min}$ at $93^{\circ} \mathrm{C}$, target DNA was amplified in 30 cycles. Each cycle consisted of denaturation for $1 \mathrm{~min}$ at $92{ }^{\circ} \mathrm{C}$, annealing for $1 \mathrm{~min}$ at $55^{\circ} \mathrm{C}$ and extension for $2 \mathrm{~min}$ at $72^{\circ} \mathrm{C}$. The final extension was for $3 \mathrm{~min}$ at $72^{\circ} \mathrm{C}$. 
The PCR reaction tubes, each containing an amplified $16 \mathrm{~S}$ rDNA fragment were held at $4{ }^{\circ} \mathrm{C}$ until further analysis.

The PCR products were purified with the Wizard purification kit (Promega; Dade Diagnostics) according to the manufacturer's instructions. 16S rDNA fragments were sequenced directly using dideoxy terminator cycle sequencing chemistry in an ABI 377 automated sequencer (Perkin Elmer; Applied Biosystems). PCR reactions were performed with AmpliTaq DNA polymerase (Perkin Elmer). In addition to primers $\mathrm{pA}$ and $\mathrm{pH}^{*}$, the following sequencing primers, complementary to internal regions of the 16S rRNA gene, were used (Hutson et al., 1993): Sef 1 (forward) 5'CGT GCC AGC AGC CGC GGT AAT-3'; Sef 2 (forward) 5'-GGA GCA TGT GGT TTA ATT CG-3'; Ser 1 (reverse) 5'-CAC GAC ACG AGC TGA CGA CAA C-3'; Ser 2 (reverse) $5^{\prime}$-CTA CGC ATT TCA CCG CTA CAC-3'; and Ser 3 (reverse) 5'-GCC GTG TCT CAG TCC CAA TGT-3'. The sequences were aligned using Sequence Navigator (Perkin Elmer) and corrected manually in agreement with the electropherograms and the reading of complementing and overlapping fragments.

(iv) Phylogenetic analysis. To find the nearest relative of strains SPL77A $^{\mathrm{T}}$ and SPL77B, sequences of these strains were compared with sequences of micro-organisms in the EMBL and GenBank databases using the program FASTA (Pearson \& Lipman, 1988). To determine the phylogenetic position of the isolates, their sequences and the sequences of their closest relations belonging to the Clostridium subphylum were aligned using the PILEUP program (Devereux et al., 1984). The alignment was corrected manually and approximately 100 nucleosides at the $5^{\prime}$ end of the molecule were omitted from further analyses because of sequence ambiguities. 16S rRNA sequence similarities were calculated and corrected for substitution rates according to Kimura (1980). A phylogenetic tree was constructed using pairwise analysis and the neighbour-joining method (Saitou \& Nei, 1987). The stability of relationships was assessed using the programs SEQBOOT, DNADIST, NEIGHBOR and CONSENSE of the PHYLIP package (Felsenstein, 1989). At least 1000 bootstrap trees were generated for each data set.

\section{Differentiation from phylogenetically related clostridia}

For SDS-PAGE of total soluble cell proteins and for cellular fatty acid (CFA) analysis, strains SPL77A ${ }^{\mathrm{T}}$, SPL77B and the reference strain of $C$. algidicarnis $\left(\mathrm{NCFB} 2931^{\mathrm{T}}\right.$ ) were grown in PYGS broth at $30^{\circ} \mathrm{C}$ for $24 \mathrm{~h}$. The remaining reference strains of phylogenetically related clostridia were grown in PYGS broth at $37^{\circ} \mathrm{C}$ for $24 \mathrm{~h}$. Cells were harvested by centrifugation at $6000 \mathrm{~g}$ for $15 \mathrm{~min}$, washed and suspended in sterile ultra-pure water to obtain a bacterial suspension with $\mathrm{OD}_{550}$ of 1.5 units.

(i) Soluble cell protein profiles. For SDS-PAGE, a $0 \cdot 3-0.5 \mathrm{ml}$ volume of bacterial suspension was sonicated on ice with an ultrasound probe (Kontes CV 18; Biolab Scientific) at a maximum output of $90 \mathrm{~W}$. Three 1-min bursts, with cooling on ice between each burst, were used to disrupt the cells. Sonicated samples were mixed in a 1:1 ratio with an SDS sample buffer containing Tris/ $\mathrm{HCl}, 20 \%$ (w/v) SDS, 2mercaptoethanol, bromophenol blue and water. Low- and broad-range protein standards (Bio-Rad) were mixed with the sample SDS buffer in the ratio 1:20. Samples and standards were denatured by boiling for $5 \mathrm{~min}$. Portions $(30 \mu \mathrm{l})$ of these denatured samples and $10 \mu \mathrm{l}$ standards were loaded in the wells of a $4-15 \%$ gradient Tris $/ \mathrm{HCl}$ poly- acrylamide gel (Bio-Rad) and subjected to electrophoresis. SDS-PAGE was performed using the discontinuous buffer system of Laemmli (1970) in a Mini Protean II vertical gel apparatus (Bio-Rad). Electrophoresis was carried out at constant voltage of $150 \mathrm{~V}$ for $1 \mathrm{~h}$ at $15^{\circ} \mathrm{C}$. The gel was stained with $0.125 \%(\mathrm{w} / \mathrm{v})$ Coomassie blue R-250 (BDH) dissolved in $50 \%(\mathrm{v} / \mathrm{v})$ aqueous methanol and $10 \%(\mathrm{v} / \mathrm{v})$ aqueous acetic acid. The gel was destained in a solution containing $50 \%(\mathrm{v} / \mathrm{v})$ aqueous methanol and $10 \%(\mathrm{v} / \mathrm{v})$ aqueous acetic acid. To assess similarities between protein profiles of individual strains, a scanned image of the destained gel was analysed with a Molecular Imager and Molecular Analyst software (Bio-Rad).

(ii) CFA analysis. For CFA analysis, fatty acid methyl esters (FAME) were extracted as described by Kuykendall et al. (1988). Briefly, $40 \mathrm{mg}$ (wet wt) cells of each strain were saponified by heating at $100{ }^{\circ} \mathrm{C}$ for $30 \mathrm{~min}$ with $1 \mathrm{ml} 15 \%$ (w/v) $\mathrm{NaOH}$ in $50 \%$ (v/v) aqueous methanol. Samples were cooled at ambient temperature, then $1.5 \mathrm{ml} 25 \%(\mathrm{v} / \mathrm{v}) \mathrm{HCl}$ in $50 \%(\mathrm{v} / \mathrm{v})$ aqueous methanol was added and the mixture was heated at $100^{\circ} \mathrm{C}$ for $15 \mathrm{~min}$. FAME were extracted with a mixture of hexane and methyl-tert-butyl ether $(1: 1, \mathrm{v} / \mathrm{v})$. The $\mathrm{C} 10-\mathrm{C} 20$ fatty acids were identified and quantified using a Hewlett Packard 6890 GC equipped with a 60 $\mathrm{m} \times 0.25 \mathrm{~mm}, 0.25 \mu \mathrm{m}$ BPX 70 column (GBC Scientific), an FID and a Hewlett Packard model 7673 automatic sampler. The GC parameters were as follows: mean linear velocity, $22 \mathrm{~cm} \mathrm{~s}^{-1}$; column head pressure, $210 \mathrm{kPa}$; split vent flow of helium carrier gas, $44 \mathrm{ml} \mathrm{min}{ }^{-1}$; constant column flow,

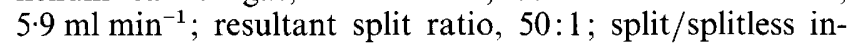
jector and FID detector temperature, $250^{\circ} \mathrm{C}$. Run conditions were: initial temperature $100^{\circ} \mathrm{C}$ for $4 \mathrm{~min}$, raised to $130{ }^{\circ} \mathrm{C}$ at $10^{\circ} \mathrm{C} \mathrm{min}^{-1}$, then raised to $150{ }^{\circ} \mathrm{C}$ at $1^{\circ} \mathrm{C} \mathrm{min}^{-1}$, raised to $200^{\circ} \mathrm{C}$ at $2.5^{\circ} \mathrm{C} \mathrm{min}^{-1}$, final temperature of $240^{\circ} \mathrm{C}$ held for 2 min after raising at a rate of $25^{\circ} \mathrm{C} \mathrm{min}-1$. Peaks were automatically integrated (Chemstation v.4) and FAME were identified and quantified against retention times and peak areas of known standards. Peaks that did not have retention times identical to those of the standards were reported as unknown compounds at their respective equivalent chain-length (Christie, 1989).

\section{RESULTS}

While strains SPL77A ${ }^{\mathrm{T}}$ and SPL77B were initially isolated from the 'blown' temperature-abused vacuum pack of raw beef, an additional 34 SPL $77 \mathrm{~A}^{\mathrm{T}}$-like and SPL77B-like isolates were subsequently obtained from faeces, hides and tonsils of bovine slaughter stock ( $J$. A. Boerema, D. M. Broda \& R. G. Bell, unpublished results). Preliminary morphological and biochemical characteristics were determined for these additional isolates and they were found to be identical to those of either SPL77A $\mathrm{A}^{\mathrm{T}}$ or SPL77B. Consequently, only characteristics of the two original meat-derived strains are described in this study.

\section{Phenotypic characterization}

The colonies of strain SPL77A ${ }^{\mathrm{T}}$ grown on the surface of CBA containing $5 \%$ sheep blood were circular to irregular with undulate to lobate margins, creamy grey, raised, low convex, shiny and opaque. The 

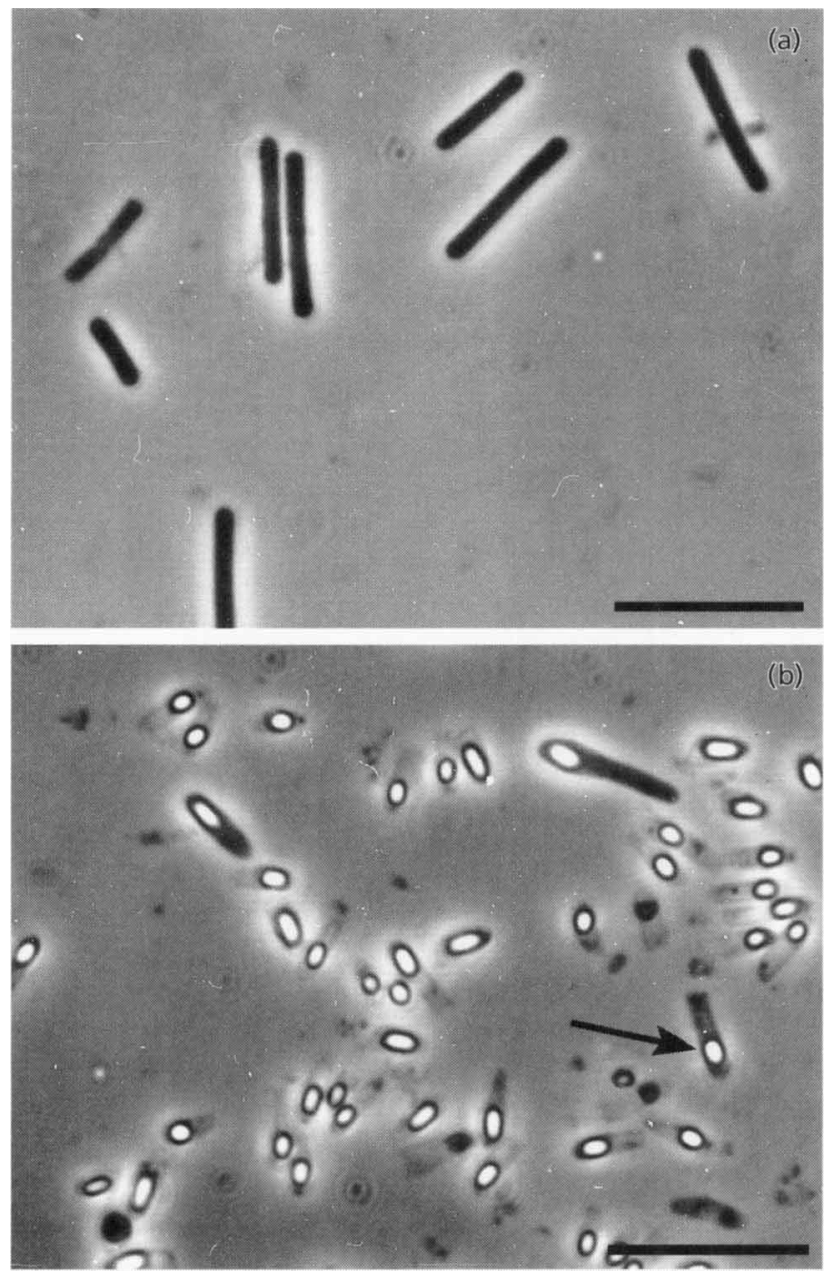

Fig. 1. Phase-contrast micrographs of vegetative (a) and sporulated (b) cells of strain SPL77A ${ }^{\top}$. The subterminal position of the spore in the cell is indicated with an arrow. Bar, $10 \mu \mathrm{m}$.

colonies measured $2 \cdot 2-3 \cdot 2 \mathrm{~mm}$ in diameter. The colonies of strain SPL77B were irregular with erose margins, grey, flat to raised, shiny, semi-opaque to translucent and measured 3.3-7.2 mm. Both strains produced large zones of $\beta$-haemolysis. With both strains, cells in exponential growth phase were roundended, straight to slightly bent rods $4 \cdot 5-9 \cdot 4 \mu \mathrm{m}$ long and $1.3-1.6 \mu \mathrm{m}$ wide (Fig. 1a). These rods occurred singly or in pairs and were motile by means of three to seven peritrichous flagella per cell (Fig. 2a). Electron micrographs of ultra-thin sections from vegetative cells showed that the organism was rod-shaped (Fig. $3 a)$ and frequently produced excess membranes during cell division (Fig. 3b). The Gram-positive-type, single layer cell wall was observed in ultra-thin sections of vegetative cells of both strains (Fig. 3c). Elliptical, subterminal spores were formed, starting during early stationary growth phase (Figs $1 \mathrm{~b}$ and $4 \mathrm{a}$ ). The sporulated cells were motile and carried peritrichous flagella (Fig. 2b). The spores caused swelling of the maternal cells. As observed in electron micrographs,

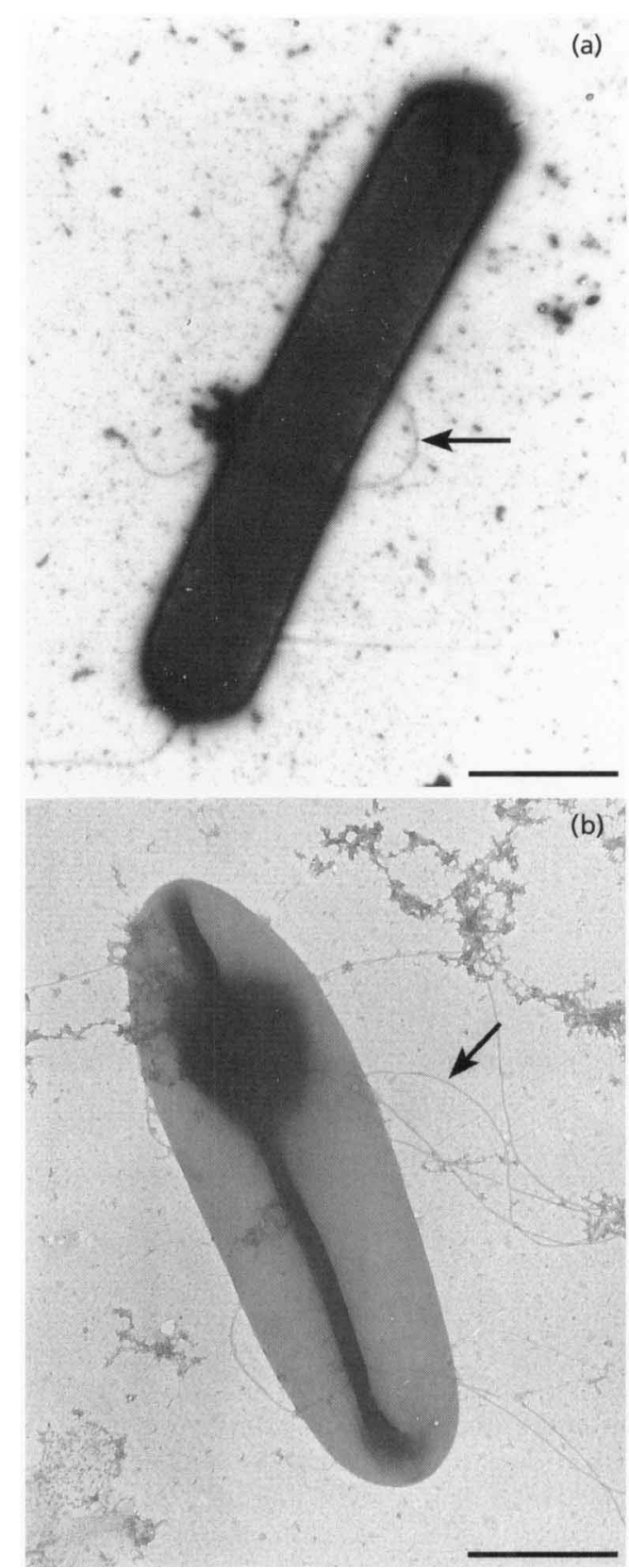

Fig. 2. Electron micrographs of negatively stained cells of strain SPL77A ${ }^{\top}$ showing peritrichous flagella (arrow) in both a vegetative (a) and a sporulated (b) cell. Bar, 1.5 $\mu \mathrm{m}$.

the mature spores had a fully developed endospore structure (Fig. 4b).

With both strains SPL77A ${ }^{\mathrm{T}}$ and SPL77B, cells in exponential growth phase stained Gram-positive. The $\mathrm{KOH}$ reaction was always negative (i.e. characteristic of Gram-positive cells) irrespective of growth medium or age of the culture. This Gram-positive type was confirmed by the single layer cell wall, as observed in electron micrographs of ultra-thin sections (Fig. 3c).

Both strains grew optimally at $30 \cdot 0-38.5{ }^{\circ} \mathrm{C}$ (Fig. 5a 


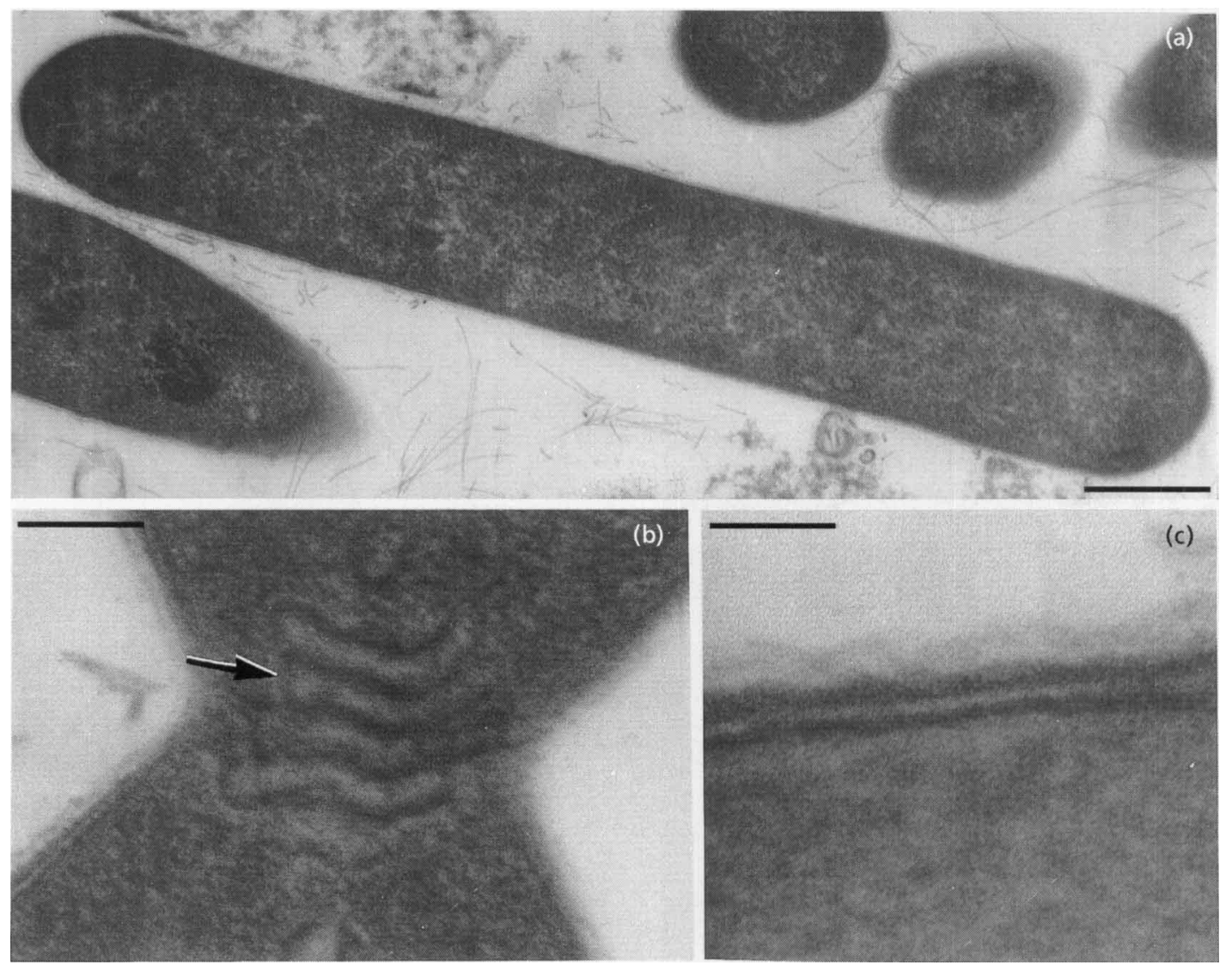

Fig. 3. Electron micrographs of thin sections of vegetative cells of strain SPL77A ${ }^{\top}$ showing (a) cell shape (bar, $\left.0.5 \mu \mathrm{m}\right)$, (b) the excess of membranes at the site of cell division (arrow; bar, $150 \mathrm{~nm}$ ) and (c) Gram-positive type cell wall (bar, $50 \mathrm{~nm}$ ).

and data not shown). The lowest temperature at which growth of strain SPL77. ${ }^{\mathrm{T}}$ was observed was $3.8^{\circ} \mathrm{C}$ and the highest temperature at which growth was observed was $40.5^{\circ} \mathrm{C}$. The optimal $\mathrm{pH}$ for growth of both strains was 6.4-7.2 and growth occurred at $\mathrm{pH}$ values between 4.7 and 9.5 (Fig. $5 \mathrm{~b}$ and data not shown). Strains SPL77A ${ }^{\mathrm{T}}$ and SPL77B required anaerobic conditions for growth.

The substrates that supported growth resulting in acidification of the growth medium by strain SPL77 ${ }^{\mathrm{T}}$ in the presence of $0.1 \%(\mathrm{w} / \mathrm{v})$ yeast extract were: fructose, glucose, maltose, mannose, sorbitol and trehalose. Cellobiose supported growth but the growth medium was only weakly acidified. Gelatin was hydrolysed, lecithinase activity was present, casein and meat were digested, and ammonia and hydrogen sulphide were produced. The milk reaction was positive for both digestion and curd formation. Addition of Tween 80 did not stimulate growth. The remaining substrate utilization tests were negative. With the Rapid ID 32 A, positive reactions were observed for $\beta$ $\mathrm{N}$-acetylglucosaminidase and proline arylamidase and weak reactions were observed for arginine arylamidase and pyroglutamic acid arylamidase. Strain SPL77B was positive or negative for the same biochemical tests as strain SPL77 $\mathrm{A}^{\mathrm{T}}$, with the exception that meat, casein and milk were only weakly digested and $\beta-N$ acetylglucosaminidase activity was not present in strain SPL77B.

The major fermentation products formed by strain SPL77A ${ }^{\mathrm{T}}$ in PYGS broth were: acetate $(43-45 \mathrm{mM})$, ethanol $(19-20 \mathrm{mM})$, butyrate $(18-20 \mathrm{mM})$, isovalerate $(6-7 \mathrm{mM})$, butanol $(4-5 \mathrm{mM})$, isobutyrate (2-3 mM), oxalacetate (1-2 mM), lactate (1 mM), hydrogen and carbon dioxide. The major fermentation products formed by strain SPL77B were: ethanol (22-26 mM), acetate $(23-25 \mathrm{mM})$, butyrate $(16-$ $17 \mathrm{mM})$, isovalerate $(2-3 \mathrm{mM})$, butanol $(1-2 \mathrm{mM})$, isobutyrate $(1 \mathrm{mM})$, oxalacetate $(1 \mathrm{mM})$, lactate (1 $\mathrm{mM})$, hydrogen and carbon dioxide.

As determined by the botulinal neurotoxin test, the supernatant of strain SPL77 $\mathrm{A}^{\mathrm{T}}$ was non-toxic to mice.

\section{Genotypic characterization}

The DNA $\mathrm{G}+\mathrm{C}$ composition was $27.3 \mathrm{~mol} \%$ for strain SPL77A ${ }^{\mathrm{T}}$ and $28.4 \mathrm{~mol} \%$ for strain SPL77B.

To establish the phylogenetic position of the unknown bacteria, the $16 \mathrm{~S}$ rRNA genes of strains SPL77A ${ }^{\mathrm{T}}$ and 


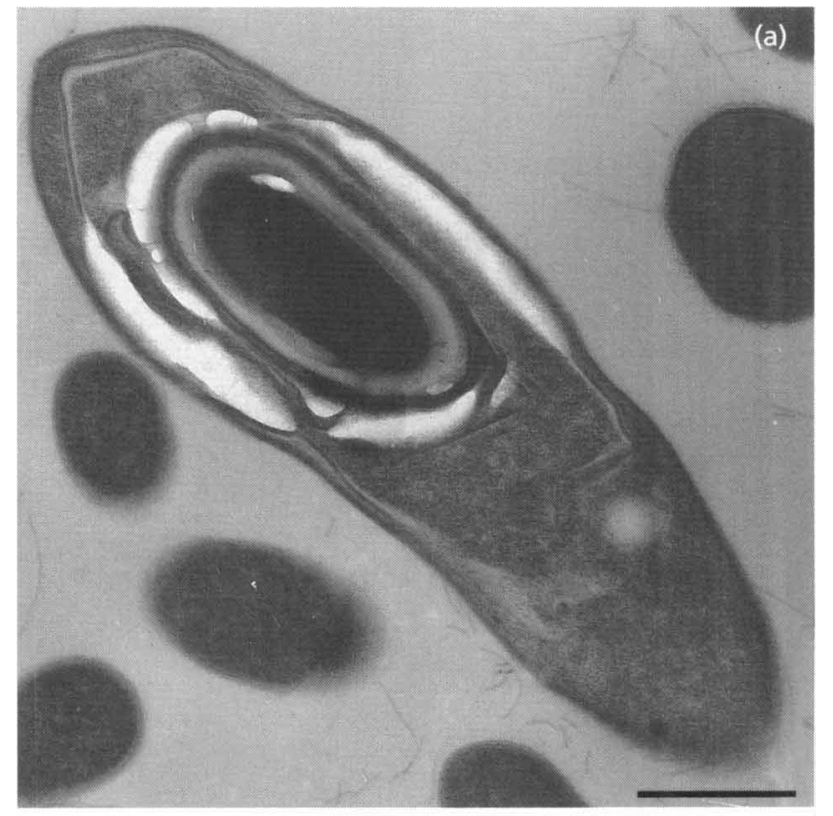

(b)

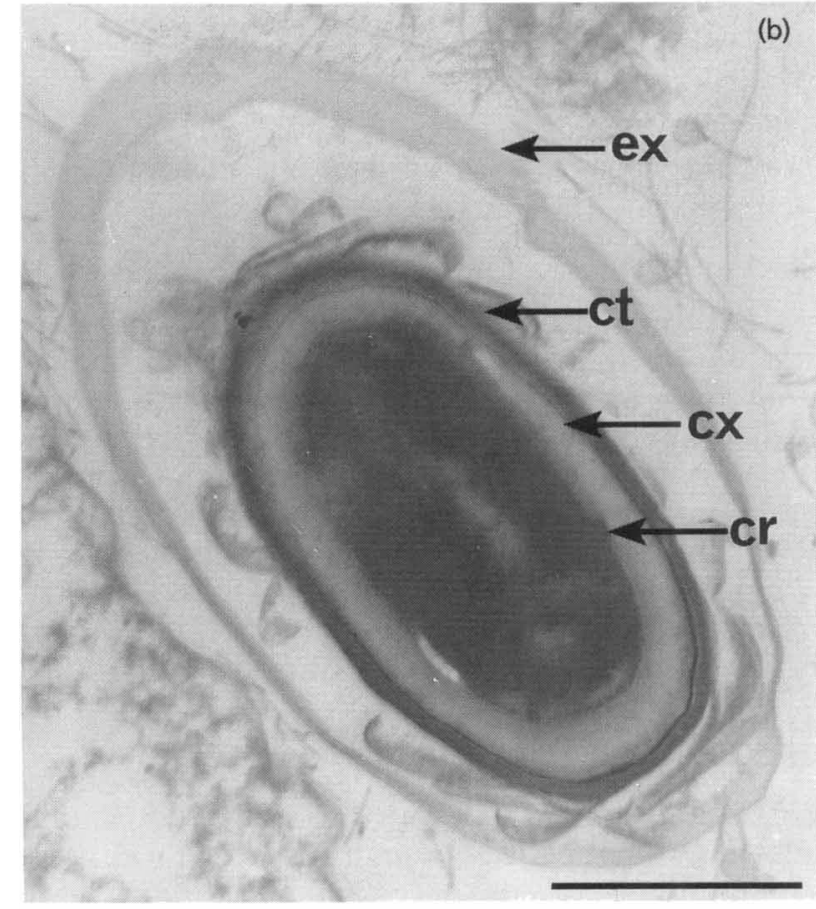

Fig. 4. Electron micrographs of thin sections of a sporulated cell of strain SPL77A ${ }^{\top}$ (a) and of a mature spore (b). Bar, $0.5 \mu \mathrm{m}$. ex, Exosporium; ct, spore coat; $c x$, cortex; and cr, spore core.

SPL77B were amplified by PCR and characterized by sequence analysis. The $16 \mathrm{~S}$ rRNA sequences for both strains consisted of a continuous stretch of 1481 and $1486 \mathrm{nt}$, respectively. This length of sequences indicates that approximately $96 \%$ of the sequence of the $16 \mathrm{~S}$ rRNA molecule was determined. Pairwise analysis of the almost complete gene sequences of the two meat isolates showed them to be genealogically homogeneous ( $100 \%$ 16S rRNA sequence similarity). Se-
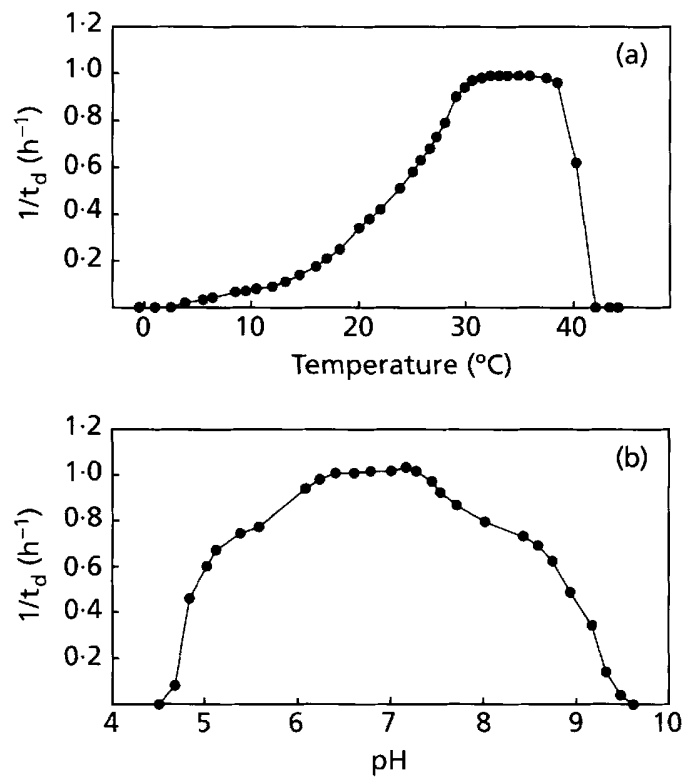

Fig. 5. Growth of strain SPL77A ${ }^{\top}$ at various incubation temperatures at $\mathrm{pH} 7.0$ (a) and at various $\mathrm{pH}$ values at $30^{\circ} \mathrm{C}(\mathrm{b})$. $t_{d}$, Doubling time.

quence searches of GenBank and the Ribosomal Database Project databases revealed that the unknown Gram-positive rod was phylogenetically most closely associated with the Clostridium subphylum (data not shown) and, in particular, to Cluster I clostridia (sensu Collins et al., 1994). The sequences of the nearest relatives of the unknown organism were retrieved and subjected to comparative analysis to determine the phylogenetic position of the strains. A tree depicting the phylogenetic affinity of the unknown bacterium within the Cluster I clostridia is shown in Fig. 6. Results of sequence similarity calculations indicate that the nearest relatives of both strains are $C$. fallax (94.5\% sequence similarity), C. algidicarnis ( $94.1 \%$ ), C. intestinale $(93.9 \%), C$. cadaveris $(93.6 \%)$ and $C$. carnis $(93.5 \%)$. Detailed phylogenetic analysis not only confirmed the position of strains SPL77A ${ }^{\mathrm{T}}$ and SPL77B within Cluster I of the genus Clostridium (Fig. 6), but also the relatively low level of phylogenetic relatedness of both strains to other clostridia within this cluster.

\section{Differentiation from phylogenetically related clostridia}

Gel electrophoresis of soluble cell proteins demonstrated that strains SPL77A ${ }^{\mathrm{T}}$ and SPL77B had indistinguishable profiles. In the protein profiles of both strains, major bands occurred at approximately 130 , 45, 40, 31, 19 and $16 \mathrm{kDa}$. However, as shown in Fig. 7 , there were distinct differences in the protein profiles, as evidenced by changes in the concentration and positions of major and minor protein bands between profiles of these two meat isolates and their phylo- 


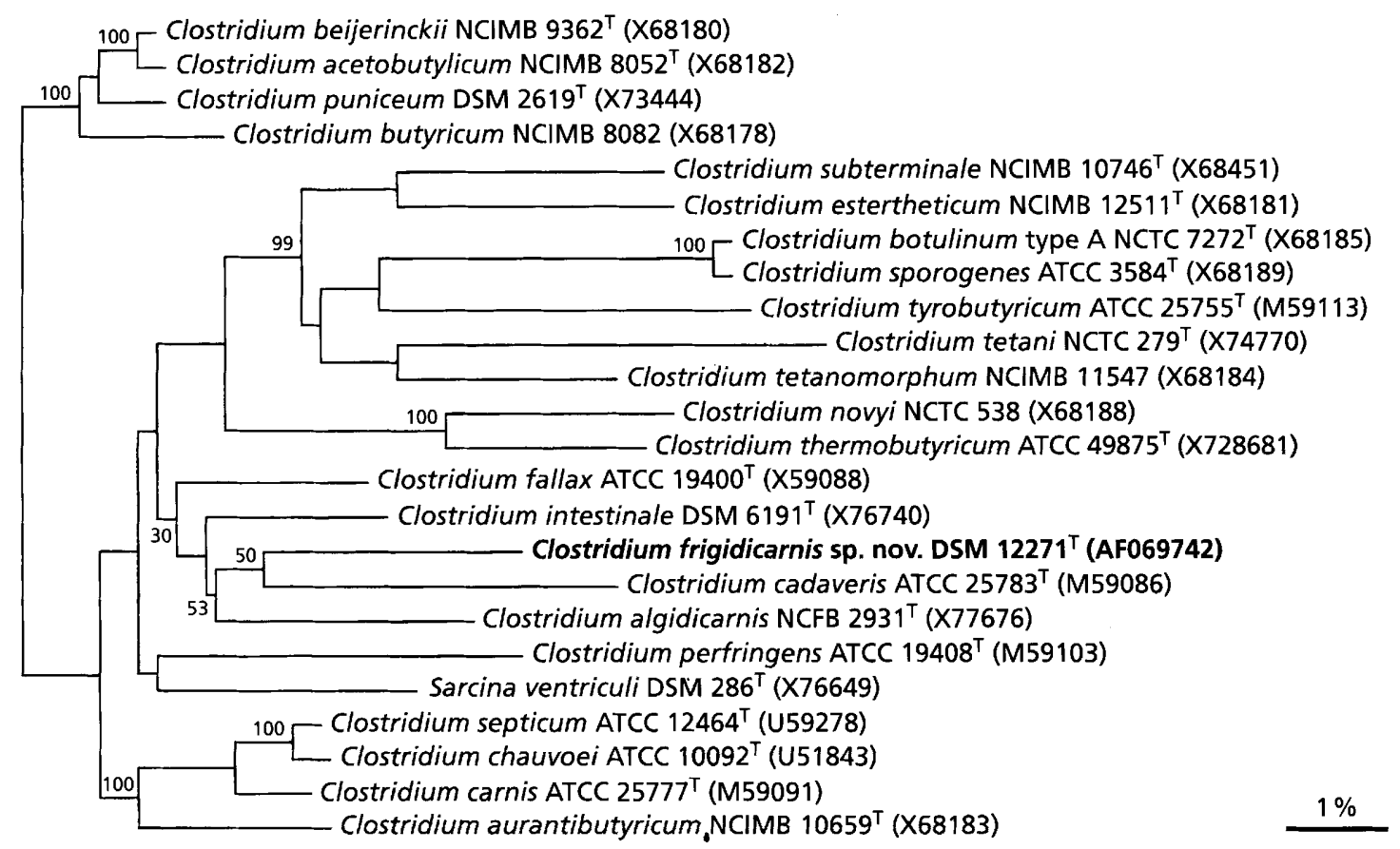

Fig. 6. Phylogenetic tree showing the relationship of strain SPL77A ${ }^{\top}$ (C. frigidicarnis sp. nov. DSM $12271^{\top}$ ) within Cluster I of the genus Clostridium (Collins et al., 1994). Bar, $1 \%$ sequence divergence. Bootstrap values are given at the branching points.

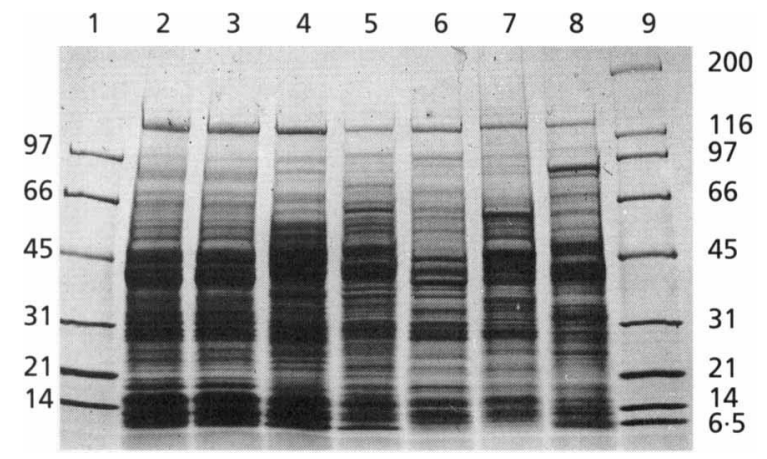

Fig. 7. SDS-PAGE of soluble cell proteins from strains SPL77A and SPL77B and other phylogenetically related clostridia. Lane

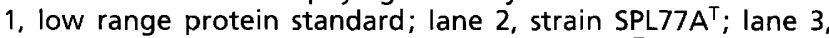
strain SPL77B: lane 4,C. fallax (DSM 2631'); lane 5, C. algidicarnis (NCFB 2931'); lane 6, C. intestinale (DSM 6191'); lane 7, C. cadaveris (DSM 1284 $)$; lane 8, C. carnis (DSM 1293'); and lane 9 , broad range protein standard. The values on the left of lane 1 and on the right of lane 9 indicate the positions of protein standards in $\mathrm{kDa}$.

genetic relatives C. fallax (DSM $2631^{\mathrm{T}}$ ), C. algidicarnis $\left(\mathrm{NCFB} 2931^{\mathrm{T}}\right), C$. intestinale (DSM 6191 $\left.{ }^{\mathrm{T}}\right), C$. cadaveris (DSM 1284 ${ }^{\mathrm{T}}$ ) and C. carnis (DSM 1293 ${ }^{\mathrm{T}}$ ).

The major CFA identified in cell extracts of strain SPL77A $^{\mathrm{T}}$ were myristic $(\mathrm{C} 14: 0,14.7 \%)$, palmitic $(\mathrm{C} 16: 0,11 \cdot 6 \%)$ and oleic $(\mathrm{C} 18: 1,6 \cdot 1 \%)$ acids. A number of minor fatty acids were also detected (Table 1). Strain SPL77B had a CFA pattern very similar to that of strain SPL $77 \mathrm{~A}^{\mathrm{T}}$. However, some differences were observed in the presence and proportions of minor fatty acids. As shown in Table 1, there were distinct differences in the CFA profiles, as evidenced by changes in the presence and proportions of major and minor fatty acids, between profiles of each of the two meat strains and their phylogenetic relatives $C$. fallax (DSM 2631 ${ }^{\mathrm{T}}$ ), C. algidicarnis (NCFB $\left.2931^{\mathrm{T}}\right), C$. intestinale (DSM 6191 $\left.{ }^{\mathrm{T}}\right)$, C. cadaveris (DSM 1284 $)$ and C. carnis $\left(\mathrm{DSM} 1293^{\mathrm{T}}\right)$.

\section{DISCUSSION}

When strains SPL77A ${ }^{\mathrm{T}}$ and SPL77B were initially isolated from spoiled vacuum-packed meat, their taxonomic status was uncertain. According to the phenotypic criteria and identification keys of Cato et al. (1986) and Holdeman et al. (1977), these strains could not be assigned to any of the clostridial species described at that time. Similarly, the Rapid ID system designed for identification of medically important anaerobes proved unsatisfactory with these microorganisms. Strains SPL77A ${ }^{\mathrm{T}}$ and SPL77B were unable to produce abundant gas in artificially inoculated chillstored packs (S. M. Moorhead, D. M. Broda \& R. G. Bell, unpublished results) and did not seem to resemble known psychrotolerant 'blown pack'-causing clostridia. In addition, the phenotypic characteristics for other psychrotolerant clostridial species discovered between 1986 and 1998 differed from those described here for strains SPL77A ${ }^{\mathrm{T}}$ and SPL77B (Collins et al., 1992; Kalchayanand et al., 1993; Lawson et al., 1994; 
Table 1. Differences in CFA composition of strains SPL77A ${ }^{\top}$, SPL77B and phylogenetically related clostridia

Values are given as percentages of total peak area. Strains: 1 , SPL77A $\mathrm{A}^{\mathrm{T}} ; 2$, SPL77B $; 3$, C. fallax DSM $2631^{\mathrm{T}} ; 4$, C. algidicarnis NCFB $2931^{\mathrm{T}} ; 5$, C. intestinale DSM $6191^{\mathrm{T}} ; 6$, C. cadaveris DSM $1284^{\mathrm{T}} ; 7$, C. carnis DSM $1293^{\mathrm{T}}$.

\begin{tabular}{|c|c|c|c|c|c|c|c|c|}
\hline $\begin{array}{l}\text { Equivalent } \\
\text { chain-length }\end{array}$ & FAME* & 1 & 2 & 3 & 4 & 5 & 6 & 7 \\
\hline $12 \cdot 000$ & $12: 0$ & - & - & 1.0 & - & $1 \cdot 2$ & - & - \\
\hline $12 \cdot 206$ & Unknown & - & - & - & $2 \cdot 6$ & - & - & - \\
\hline 14.000 & $14: 0$ & $14 \cdot 7$ & 13.6 & 6.7 & 1.7 & $5 \cdot 2$ & $12 \cdot 5$ & - \\
\hline 14.527 & $14: 1$ & $2 \cdot 8$ & $2 \cdot 0$ & - & $2 \cdot 5$ & - & - & - \\
\hline $14 \cdot 716$ & Unknown & $2 \cdot 0$ & $1 \cdot 4$ & - & - & - & - & - \\
\hline $15 \cdot 350$ & Unknown & $1 \cdot 4$ & - & $5 \cdot 1$ & $6 \cdot 7$ & $7 \cdot 6$ & $2 \cdot 4$ & $2 \cdot 0$ \\
\hline $15 \cdot 525$ & $15: 1$ & - & - & $1 \cdot 0$ & - & $1 \cdot 0$ & - & - \\
\hline 15.672 & Unknown & $3 \cdot 8$ & $2 \cdot 3$ & $1 \cdot 1$ & - & - & - & - \\
\hline 15.868 & Unknown & - & - & $2 \cdot 3$ & $3 \cdot 2$ & 3.7 & $1 \cdot 1$ & - \\
\hline 16.000 & $16: 0$ & 11.6 & $10 \cdot 2$ & $21 \cdot 3$ & $9 \cdot 2$ & 11.7 & $13 \cdot 0$ & $9 \cdot 5$ \\
\hline $16 \cdot 288$ & Unknown & - & - & $2 \cdot 2$ & - & $2 \cdot 0$ & 1.6 & $1 \cdot 8$ \\
\hline 16.336 & Unknown & 1.7 & $1 \cdot 8$ & - & - & - & - & - \\
\hline $16 \cdot 398$ & $16: 1$ & $2 \cdot 9$ & $3 \cdot 6$ & $1 \cdot 3$ & 1.5 & $5 \cdot 6$ & $1 \cdot 4$ & $2 \cdot 2$ \\
\hline $17 \cdot 000$ & $17: 0$ & - & - & - & - & - & - & $1 \cdot 4$ \\
\hline $17 \cdot 411$ & $17: 1$ cis-10 & - & - & - & - & - & - & 1.0 \\
\hline $17 \cdot 538$ & Unknown & $2 \cdot 8$ & - & $2 \cdot 2$ & $1 \cdot 8$ & 3.9 & $1 \cdot 5$ & - \\
\hline $18 \cdot 000$ & $18: 0$ & $3 \cdot 5$ & $3 \cdot 0$ & $5 \cdot 1$ & $1 \cdot 3$ & $4 \cdot 7$ & $5 \cdot 6$ & $4 \cdot 7$ \\
\hline $18 \cdot 207$ & $18: 1 \quad c i s-9$ & 3.0 & - & - & - & - & $1 \cdot 0$ & $2 \cdot 2$ \\
\hline $18 \cdot 402$ & $18: 1$ & $6 \cdot 1$ & $4 \cdot 2$ & $6 \cdot 5$ & $11 \cdot 0$ & $8 \cdot 0$ & 9.6 & $10 \cdot 6$ \\
\hline $18 \cdot 446$ & Unknown & - & - & $3 \cdot 1$ & - & $3 \cdot 1$ & - & - \\
\hline $19 \cdot 031$ & $18: 2$ & $1 \cdot 2$ & $1 \cdot 7$ & $11 \cdot 2$ & $6 \cdot 4$ & $1 \cdot 8$ & 3.8 & $1 \cdot 1$ \\
\hline $19 \cdot 426$ & $18: 3$ & - & - & - & $1 \cdot 6$ & - & - & - \\
\hline
\end{tabular}

* Only fatty acids occurring at concentrations over $1 \%$ are listed.

Table 2. Some properties which differentiate strain SPL77A ${ }^{\top}$ from phylogenetically related clostridia

Strains: $1, \mathrm{SPL}_{77 \mathrm{~A}^{\mathrm{T}}} ; 2$, C. fallax $; 3$, C. algidicarnis $; 4$, C. intestinale $; 5$, C. cadaveris $; 6$, C. carnis. Results in parentheses are for some strains of the species. + , Positive; - , negative; w, weak reaction (pH 5.5-5.9); NR, not reported.

\begin{tabular}{|c|c|c|c|c|c|c|}
\hline Phenotypic property & 1 & $2^{*}$ & $3 \dagger$ & $4 \ddagger$ & $5^{*}$ & $6^{*}$ \\
\hline Fermentation products $\S$ & $\mathrm{A}, \mathrm{B}, \mathrm{ib}, \mathrm{iv}, 1, \mathrm{o}, 2,4$ & $\mathrm{~A}, \mathrm{~B}, \mathrm{~L}(\mathrm{~s}, 2,4)$ & $\mathrm{A}, \mathrm{B}$ & $A, B(l, f, s)$ & $\mathrm{B}, \mathrm{A}, 2,4(\mathrm{f}, \mathrm{p}, 1, \mathrm{~s})$ & $\mathrm{B}, \mathrm{A}, \mathrm{L}, \mathrm{f}(\mathrm{s})$ \\
\hline Gelatin hydrolysis & + & - & - & - & + & - \\
\hline Meat digestion & + & - & - & NR & + & - \\
\hline Indole production & - & - & - & - & + & - \\
\hline Lecithinase activity & + & - & - & - & - & - \\
\hline Aesculin hydrolysis & - & + & - & + & - & + \\
\hline \multicolumn{7}{|l|}{ Fermentation of: } \\
\hline Mannose & + & + & + & + & $-(w)$ & $+(w)$ \\
\hline Sorbitol & + & $-(w)$ & - & + & - & - \\
\hline Trehalose & + & - & - & + & - & $-(w)$ \\
\hline
\end{tabular}

* Data from Cato et al. (1986).

$\dagger$ Data from Lawson et al. (1994)

$\$$ Data from Lee et al. (1989).

$\S$ A, Acetate; B, butyrate; L or 1, lactate; ib, isobutyrate; iv, isovalerate; f, formate; $p$, propionate; s, succinate; o, oxalacetate; 2 , ethanol; 4, butanol. Upper-case letters indicate major and lower-case letters indicate minor fermentation products. 
Table 3. Some properties which differentiate strain SPL77A ${ }^{\top}$ from other psychrotolerant clostridia

Strains: 1, SPL77A $;$; C. arcticum; 3, C. algidicarnis ; 4, C. botulinum non-proteolytic types B, E, F; 5, C. estertheticum; 6, C. fimetarium; 7, C. laramiense; $8, C$. putrefaciens; 9, C. vincentii. See Table 2 for abbreviations and symbols.

\begin{tabular}{|c|c|c|c|c|c|c|c|c|c|}
\hline Phenotypic property & 1 & $2^{*}$ & $3 \uparrow$ & $4 *$ & $5 \ddagger$ & $6 \S$ & $7 \|$ & $8^{*}$ & 99 \\
\hline $\begin{array}{l}\text { Maximum growth temperatur } \\
\left({ }^{\circ} \mathrm{C}\right)\end{array}$ & $40 \cdot 5$ & 37 & 37 & $<45$ & 15 & 30 & 20 & $<37$ & 20 \\
\hline $\begin{array}{l}\text { Optimum growth temperature } \\
\left({ }^{\circ} \mathrm{C}\right)\end{array}$ & e $30-38 \cdot 5$ & $22-25$ & $25-30$ & $25-30$ & $10-12$ & $20-25$ & 15 & $15-22$ & 12 \\
\hline Fermentation products & $\begin{array}{l}\mathrm{A}, \mathrm{B}, \mathrm{ib}, \mathrm{iv}, 1 \\
\quad \mathrm{o}, 2,4\end{array}$ & $\mathrm{P}, \mathrm{A}(\mathrm{b})$ & A, B & $\mathrm{B}, \mathrm{A}(\mathrm{l})$ & $\mathrm{B}, \mathrm{A}$ & $\mathrm{A}, \mathrm{F}, \mathrm{L}, 2$ & $\begin{array}{c}\mathrm{A}, \mathrm{B}, \mathrm{ib} \\
\mathrm{p}\end{array}$ & $\mathrm{a}, \mathrm{f}, 1(\mathrm{~s})$ & $\mathrm{A}, \mathrm{F}, \mathrm{B}$ \\
\hline Gelatin hydrolysis & + & - & - & + & NR & NR & - & - & NR \\
\hline Meat digestion & + & - & - & - & NR & NR & + & - & NR \\
\hline Lipase activity & - & NR & NR & + & NR & NR & + & - & NR \\
\hline Lecithinase activity & + & NR & - & - & NR & NR & - & - & NR \\
\hline Starch hydrolysis & - & - & - & + & + & - & + & - & - \\
\hline \multicolumn{10}{|l|}{ Fermentation of: } \\
\hline Cellobiose & - & w & - & - & + & + & - & - & + \\
\hline Galactose & - & NR & NR & - & + & + & + & - & + \\
\hline Lactose & - & - & - & - & NR & - & - & - & + \\
\hline Maltose & + & - & - & + & + & + & + & - & + \\
\hline Mannitol & - & w & - & - & + & - & + & - & NR \\
\hline Sorbitol & + & - & - & + & + & - & NR & - & - \\
\hline Trehalose & + & - & - & + & NR & - & - & - & NR \\
\hline Xylose & - & + & + & - & + & + & - & - & + \\
\hline
\end{tabular}

* Data from Cato et al. (1986).

$\uparrow$ Data from Lawson et al. (1994).

† Data from Collins et al. (1989).

$\S$ Data from Kotsyurbenko et al. (1995).

\| Data from Kalchayanand et al. (1993).

I Data from Mountfort et al. (1997).

Kotsyurbenko et al., 1995; Mountfort et al., 1997). Consequently, in phenotypic terms, the meat strains were either a new species or were previously described clostridial species that had been phenotypically modified by growth conditions in the laboratory.

The 16S rRNA sequence analysis demonstrated that strains SPL77A ${ }^{\mathrm{T}}$ and SPL77B are phylogenetically related to micro-organisms in Cluster I of the genus Clostridium (Collins et al., 1994). The nearest phylogenetic relatives of these meat strains are $C$. fallax $($ DSM 2631 $), C$. algidicarnis (NCFB 2931 $1^{\mathrm{T}}$ ), C. intestinale $\left(\mathrm{DSM} 6191^{\mathrm{T}}\right)$, C. cadaveris (DSM 1284 ${ }^{\mathrm{T}}$ ) and $C$. carnis (DSM 1293 ${ }^{\mathrm{T}}$ ). Sequence divergence values of the meat strains SPL77A ${ }^{\mathrm{T}}$ and SPL77B and their phylogenetic relatives of approximately $5 \cdot 5-6 \cdot 4 \%$ indicate that these meat strains should be assigned to a new species (Stackebrandt \& Goebel, 1994).

Strains SPL77A ${ }^{T}$ and SPL77B were easily differentiated from their phylogenetic neighbours by soluble protein profiles, CFA profiles and phenotypic properties (Table 2). During growth in PYGS broth, both strains produced a complex mixture of eight alcohols and volatile and non-volatile fatty acids, including ethanol, butanol, isovalerate, isobutyrate and oxalacetate. None of their near phylogenetic relatives are known to produce this combination of compounds (Cato et al., 1986; Lee et al., 1989; Lawson et al., 1993). The meat strains were lecithinase-positive, whereas their relatives are lecithinase-negative. Of five reference strains used in the comparison, only $C$. cadaveris (DSM $1284^{\mathrm{T}}$ ) hydrolyses gelatin and digests meat. This reference strain, however, produces indole, whereas strains SPL77 $\mathrm{A}^{\mathrm{T}}$ and SPL77B do not, and it is unable to ferment mannose, sorbitol and trehalose three carbohydrates fermented by the two meat strains.

Strains SPL77A ${ }^{\mathrm{T}}$ and SPL77B were able to grow at $4{ }^{\circ} \mathrm{C}$. Therefore, by the definition of Eddy (1960) they can be described as psychrotolerant. However, the phenotypic characteristics of these strains differed from those of the other psychrotolerant clostridia (Table 3). Of all the psychrotolerant strains used for comparison in this study, only the meat strains formed ethanol, butanol, isovalerate, isobutyrate and oxalacetate as fermentation products. These strains were readily distinguished from Clostridium arcticum, $C$. estertheticum, $C$. laramiense and Clostridium vincentii by their maximum and optimum growth temperature 
and substrate utilization pattern (Cato et al., 1986; Collins et al., 1992; Kalchayanand et al., 1993; Mountfort et al., 1997). In addition, $C$. laramiense exhibits lipase but not lecithinase activity, reduces nitrate but does not hydrolyse gelatin (Kalchayanand et al., 1993). Unlike C. putrefaciens, strains SPL77A ${ }^{\mathrm{T}}$ and SPL77B were both proteolytic and saccharolytic. With respect to the optimum growth temperature, the meat strains showed closest similarity with $C$. algidicarnis and non-proteolytic Clostridium botulinum types B, E or F. However, C. algidicarnis cannot hydrolyse gelatin or digest meat and utilizes a different range of substrates than strains SPL77A ${ }^{\mathrm{T}}$ and SPL 77B (Lawson et al., 1994). Non-proteolytic C. botulinum types B, E or F exhibit lipase but not lecithinase activity, can hydrolyse starch but do not digest meat or milk (Cato et al., 1986). In contrast, strains SPL77A ${ }^{\mathrm{T}}$ and SPL77B showed lecithinase but not lipase activity, did not hydrolyse starch but digested meat and milk.

Only small differences in colony morphology, physiological and biochemical reactions, DNA base composition and minor CFA were found between strains SPL77A ${ }^{\mathrm{T}}$ and SPL77B, suggesting that the two isolates are different strains of the same species.

Based on both phenotypic and phylogenetic findings, we consider that strains SPL77A $\mathrm{A}^{\mathrm{T}}$ and SPL77B merit classification as a new species within the genus Clostridium, for which we propose the name Clostridium frigidicarnis.

\section{Description of Clostridium frigidicarnis sp. nov.}

Clostridium frigidicarnis (fri.gi.di.car'nis. L. adj. frigidus cool; L. n. carno meat; N. L. gen. n. frigidicarnis of cool meat).

Colonies on sheep blood agar measure from 2.2$7.2 \mathrm{~mm}$ in diameter and are: circular to irregular; with undulate, lobate or erose margins; creamy-grey to grey; opaque or semi-opaque to translucent; and $\beta$ haemolytic. Cells are Gram-positive, motile rods (4.5$9.4 \mu \mathrm{m}$ long and $1.3-1.6 \mu \mathrm{m}$ wide) occurring singly or in pairs. Elliptical spores are produced in early stationary growth phase. Psychrotolerant and grows between 3.8 and $40.5^{\circ} \mathrm{C}$ (optimum growth temperature is $30.0-38.5^{\circ} \mathrm{C}$ ). At $30^{\circ} \mathrm{C}$, it grows between $\mathrm{pH} 4.7$ and 9.5; optimum $\mathrm{pH}$ for growth is 6.4-7.2. Fructose, glucose, mannose, mannitol and trehalose are fermented, lecithinase activity is present and gelatin is hydrolysed. Fermentation products formed in PYGS broth are acetate, ethanol, butyrate, isovalerate, butanol, isobutyrate, oxalacetate, lactate, hydrogen and carbon dioxide. Major CFA are myristic, palmitic and oleic acids. DNA $\mathrm{G}+\mathrm{C}$ composition is $27 \cdot 3-28 \cdot 4$ $\mathrm{mol} \%$. Isolated from vacuum-packed temperatureabused beef and from faeces, hides and tonsils of bovine slaughter stock. Possibly forms a part of a normal flora of vacuum-packed chilled meats. The type strain is strain SPL77A ${ }^{\mathrm{T}}$ (= DSM $12271^{\mathrm{T}}$ ).

\section{ACKNOWLEDGEMENTS}

The authors wish to thank Mr D. J. C. Wild for help with the transmission electron microscopy, Mr M. P. Agnew for assistance with chromatography and $\mathrm{Mr} \mathrm{M}$. Wilson for conducting toxigenicity tests. The financial support of the New Zealand Foundation for Research, Science and Technology is gratefully acknowledged.

\section{REFERENCES}

Beveridge, T. J., Popkin, T. J. \& Cole, R. M. (1994). Electron microscopy. In Methods for General and Molecular Bacteriology, pp. 42-71. Edited by P. Gerhardt, R. G. E. Murray, W. A. Wood \& N. R. Krieg. Washington, DC: American Society for Microbiology.

Broda, D. M., De Lacy, K. M., Bell, R. G., Braggins, T. J. \& Cook, R. L. (1996). Psychrotrophic Clostridium spp. associated with 'blown pack' spoilage of chilled vacuum-packed red meats and dog rolls in gas-impermeable plastic casings. Int $J$ Food Microbiol 29, 335-352.

Callow, E. H. \& Ingram, M. (1955). Bone taint in beef. Food 24, $52-55$.

Cato, E. P., George, W. L. \& Finegold, S. M. (1986). Genus Clostridium Prazmowski 1880, 23 ${ }^{\wedge \mathrm{L}}$. In Bergey's Manual of Systematic Bacteriology, vol. 2, pp. 1141-1200. Edited by P. H. A. Sneath, N. S. Mair, M. E. Sharpe \& J. G. Holt. Baltimore: Williams \& Wilkins.

Christie, w. W. (1989). Gas chromatographic analysis of fatty acid derivatives. In Gas Chromatography and Lipids, pp. 85-128. Edited by W. W. Christie. Ayr, UK: Oily Press.

Collins, M. D., Rodriques, U. M., Dainty, R. H., Edwards, R. A. \& Roberts, T. A. (1992). Taxonomic studies on a psychrophilic Clostridium from vacuum-packed beef: description of Clostridium estertheticum sp. nov. FEMS Microbiol Lett 96 , 235-240.

Collins, M. D., Lawson, P. A., Willems, A., Cordoba, J. J., Fernandez-Garayzabal, J., Garcia, P., Cai, J., Hippe, H. \& Farrow, J. A. E. (1994). The phylogeny of the genus Clostridium: proposal of five new genera and eleven new species combinations. Int $J$ Syst Bacteriol 44, 812-826.

Dainty, R. H., Edwards, R. A. \& Hibbard, C. M. (1989). Spoilage of vacuum-packed beef by a Clostridium sp. I Sci Food Agric 49, 473. 486 .

Devereux, J., Haeberli, P. \& Smithies, O. (1984). A comprehensive set of sequence analysis programs for the VAX. Nucleic Acids Res 12, 387-395.

Eddy, B. P. (1960). The use and meaning of the term 'psychrophilic'. J Appl Bacteriol 23, 189-190.

Felsenstein, J. (1989). PHYLIP - Phylogeny inference package (version 3.2). Cladistics 5, 164-166.

Gill, C. O. (1979). A review: intrinsic bacteria in meat. $J$ Appl Bacteriol 47, 473-486.

Holdeman, L. V., Cato, E. P. \& Moore, W. E. C. (1977). Anaerobe Laboratory Manual, 4th edn. Blacksburg, VA: Virginia Polytechnic Institute and State University.

Hutson, R. A., Thompson, D. E. \& Collins, M. D. (1993). Genetic interrelationships of saccharolytic Clostridium botulinum types $B, E$ and $F$ and related clostridia as revealed by small-subunit rRNA gene sequences. FEMS Microbiol Lett 108, 103-110.

Ingram, M. (1952). Internal bacterial taints ('bone taint' or 'souring') of cured pork legs. J Hyg (Cam) 50, 165-181. 
Johnson, J. L. (1994). Similarity analysis of DNAs. In Methods for General and Molecular Bacteriology, pp. 655-682. Edited by P. Gerhardt, R. G. E. Murray, W. A. Wood \& N. R. Krieg. Washington, DC: American Society for Microbiology.

Johnson, M. J., Thatcher, E. \& Cox, M. E. (1995). Techniques for controlling variability in Gram staining of obligate anaerobes. $J$ Clin Microbiol 33, 755-758.

Kalchayanand, N., Ray, B. \& Johnson, M. C. (1989). Spoilage of vacuum-packaged beef by Clostridium. J Food Protein 52, 424-426.

Kalchayanand, N., Ray, B. \& Field, R. A. (1993). Characteristics of psychrotrophic Clostridium laramie causing spoilage of vacuum-packaged refrigerated fresh and roasted beef. $J$ Food Protein 56, 13-17.

Kimura, M. (1980). A simple method for estimating evolutionary rates of base substitutions through comparative studies of nucleotide sequences. $J$ Mol Evol 16, 111-120.

Kotsyurbenko, O. R., Nozhevnikova, A. N., Osipov, G. A., Kostrikina, N. A. \& Lysenko, A. M. (1995). A new psychroactive bacterium Clostridium fimetarium, isolated from cattle manure digested at low temperature. Mikrobiologiya 64, 804-810.

Kuykendall, L. D., Roy, M. A., O’Neill, J. J. \& Devine, T. E. (1988). Fatty acids, antibiotic resistance and deoxyribonucleic acid homology groups of Bradyrhizobium japonicum. Int J Syst Bacteriol 38, 358-361.

Laemmli, U. K. (1970). Cleavage of structural proteins during the assembly of the head of bacteriophage T4. Nature 227, 680-685.

Lawson, P., Dainty, R. H., Kristiansen, N., Berg, J. \& Collins, M. D. (1994). Characterization of a psychrotrophic Clostridium causing spoilage in vacuum-packed cooked pork: description of Clostridium algidicarnis sp. nov. Lett Appl Microbiol 19, 153-157.

Lee, W.-K., Fujisawa, T., Kawamura, S., Itoh, K. \& Mitsuoka, T. (1989). Clostridium intestinalis sp. nov., an aerotolerant species isolated from the feces of cattle and pigs. Int J Syst Bacteriol 39, 334-336.

Lund, B. M., Graham, A. F., George, S. M. \& Brown, D. (1990). The combined effect of incubation temperature, $\mathrm{pH}$ and sorbic acid on the probability of growth of non-proteolytic type B Clostridium botulinum. $J$ Appl Bacteriol 69, 481-492.
Marmur, J. (1961). A procedure for the isolation of deoxyribonucleic acid from microorganisms. $J \mathrm{Mol} \mathrm{Biol} \mathrm{3,} \mathrm{208-218.}$

Mesbah, M., Premachandran, U. \& Whitman, W. B. (1989). Precise measurement of the $\mathrm{G}+\mathrm{C}$ content of deoxyribonucleic acid by high-performance liquid chromatography. Int $J$ Syst Bacteriol 39, 159-167.

Mountfort, D. O., Rainey, F. A., Burghardt, J., Kaspar, H. F. \& Stackebrandt, E. (1997). Clostridium vincentii sp. nov., a new obligately anaerobic, saccharolytic, psychrophilic bacterium isolated from low-salinity pond sediment of the McMurdo Ice Shelf, Antarctica. Arch Microbiol 167, 54-60.

Pearson, W. R. \& Lipman, D. J. (1988). Improved tools for biological sequence comparison. Proc Natl Acad Sci USA 85, 2444-2448.

Powers, E. M. (1995). Efficacy of the Ryu nonstaining $\mathrm{KOH}$ technique for rapidly determining Gram reactions of foodborne and waterborne bacteria and yeasts. Appl Environ Microbiol 61, 3756-3758.

Roberts, T. A. \& Mead, G. C. (1986). Involvement of intestinal anaerobes in the spoilage of red meats, poultry and fish. In Anaerobic Bacteria in Habitats Other Than Man, pp. 333-349. Edited by E. M. Barnes \& G. C. Mead. Oxford: Blackwell Scientific.

Ross, H. E. (1965). Clostridium putrefaciens: a neglected anaerobe. J Appl Bacteriol 28, 49-51.

Saitou, N. \& Nei, M. (1987). The neighbor-joining method: a new method for reconstructing phylogenetic trees. Mol Biol Evol 4, 406-425.

Solomon, H. M., Rhodehamel, E. J. \& Kautter, D. A. (1995). Clostridium botulinum. In Food and Drug Administration Bacteriological Analytical Manual, 8th edn, pp. 17.01-17.10. Gaithersburg: AOAC International.

Stackebrandt, E. \& Goebel, B. M. (1994). Taxonomic note: a place for DNA-DNA reassociation and 16S rRNA sequence analysis in the present species definition in bacteriology. Int $J$ Syst Bacteriol 44, 846-849.

Trüper, H. G. \& De' Clari, L. (1997). Taxonomic note: necessary correction of specific epithets formed as substantives (nouns) 'in apposition'. Int J Syst Bacteriol 47, 908-909. 